\title{
Density and abundance of Rhea pennata garleppi (Struthioniformes: Rheidae) in the Puna ecoregion of Argentina
}

\author{
Nancy Verónica Marinero ${ }^{1 *}$, Ricardo Omar Cortez ${ }^{2}$, Joaquín Luis Navarro ${ }^{1}$ and Mónica Beatriz Martella
}

\begin{abstract}
Background: Rhea pennata is classified internationally as a near-threatened species, with the subspecies R. p. garleppi being listed as endangered.

Finding: The aim of this study was to provide updated information on the density and abundance of R. p. garleppi in the southern Puna ecoregion of Argentina. Density was estimated indirectly on the basis of monthly feces counts during 2011 and 2012, using line-transect surveys. Monthly abundance was calculated by multiplying the density of each month by the area of the reserve $\left(400 \mathrm{~km}^{2}\right)$. Population size range was calculated considering the average of the months with the highest abundance (and density) as the upper limit and the average of the months with the lowest abundance (and density) as the lower limit. The population size of this subspecies varied between 300 individuals $( \pm 60)$, with a density of 0.75 individual $/ \mathrm{km}^{2}( \pm 0.15)$ during the non-breeding season, and 188 individuals $( \pm 40)$, with a density of 0.47 individuals $/ \mathrm{km}^{2}( \pm 0.10)$, during the reproductive season.
\end{abstract}

Conclusion: This work shows the highest density record for $R$. p. garleppi so far and highlights changes in population size related to life history characteristics of rheas, as well as human factors that negatively affect the survival of wild populations.

Keywords: Rhea pennata garleppi; Puna; Conservation; Andean precordillera

\section{Findings}

The family Rheidae is endemic to the Neotropics and comprises two species of large flightless birds: Rhea americana and Rhea (Pterocnemia) pennata (Blake 1977). R. pennata includes three subspecies: $R$. p. pennata, present in southern Chile and west-central and southern Argentina, in the Andean Precordillera steppes and Patagonian plateaus up to $2,000 \mathrm{~m}$ above sea level (a.s.l.); $R$. $p$. tarapacensis, which is distributed throughout northern Chile; and R. p. garleppi, occurring in southern Peru, southwestern Bolivia, and northwestern Argentina. The latter two subspecies inhabit open plains with grasslands, shrublands, and in the intermountain valleys of the Puna plateau above 3,500 m a.s.l. (Plenge 1982; Cajal 1988; Folch 1992).

\footnotetext{
* Correspondence: veronicamarinero@gmail.com

${ }^{1}$ Instituto de Diversidad y Ecología Animal (Consejo Nacional de

Investigaciones Científicas y Técnicas Universidad Nacional de Córdoba), Centro de Zoología Aplicada, Universidad Nacional de Córdoba, Rondeau 798, Córdoba X5000AVP, Argentina

Full list of author information is available at the end of the article
}

Wild populations of $R . p$. garleppi are found in low densities, with severe fluctuations throughout the species' distribution range, and with a tendency to decrease or become locally extinct in many cases (Cajal 1988; Chebez 2008). In the Puna, the main factors that negatively affect wild populations of this ratite are hunting for meat consumption and egg harvesting as subsistence resources (Barbarán 2004; Hernandez 2011). Another threat is the use by local people of by-products, such as feathers, skin, fat, and bones (Barbarán 2004). In this scenario, and in order to ensure their long-term conservation, the subspecies $R . p$. garleppi is considered at risk of extinction (CITES 2014) and $R$. pennata has been categorized as near-threatened (IUCN 2014). However, the lack of knowledge regarding the current status of wild populations of $R$. p. garleppi hinders the conservation of this subspecies. The aim of this study was to provide updated information on the density and abundance of $R$. p. garleppi in the southern Puna ecoregion of Argentina. 
This study was conducted in Don Carmelo Private Reserve $\left(400 \mathrm{~km}^{2}\right)$, located on the Andean Precordillera of San Juan province in Argentina (30 $56^{\prime} 52^{\prime \prime}$ S, 69 $05^{\prime} 02^{\prime \prime}$ W; 3,100 m a.s.l.). The Reserve is located in the Argentine Puna ecoregion, in the southeastern border of the Altiplano in the central Andes (Bonaparte 1978). The climate is arid and cold, with intense solar radiation, strong winds, and daily temperature fluctuations that may exceed $30^{\circ} \mathrm{C}$ (Reboratti 2006). Precipitations are scarce and occur between November and February, decreasing to the west and south of the Puna (Cabrera and Willink 1973). The reserve is located in the subregion known as dry Puna due to the lack of permanent rivers and lakes (Cabrera 1976). The dominant habitat is the shrub-steppe, with a mean altitude of $13.9 \mathrm{~cm}( \pm 0.72)$, and the vegetation is xerophilous, with $88 \%$ of bare soil (Cappa et al. 2014). Wild populations of $R$. p. garleppi inhabiting similar environments use indistinctly both the grassland plains of Stipa spp. and low shrublands of Adesmia spp, as well as the rocky and non-rocky mountain slopes with shrubs of Lycium spp. and Adesmia spp. and low cover of Stipa spp. (Cajal 1998). Don Carmelo Private Reserve is a suitable site for the subspecies garleppi because it is not fragmented or disturbed by mining or agricultural activities, and massive tourism is banned.

It is difficult to perform direct observation or monitoring of $R . p$. garleppi in the study area because these birds run long distances at great speed, their plumage color allows them to mimic the environment, and the topography of the area is irregular. Therefore, we decided to use the fecal count technique as an indirect method for estimating population density (Ojasti and Dallmeier 2000). This method has been used effectively in other studies on wild populations of rheas (Bazzano et al. 2002; Herrera et al. 2004; Kusch and Henríquez 2011). Six samplings were conducted between 2011 and 2012 (September and November 2011; March, April, July, and November 2012). In each sampling, 20 randomized transects were spaced at least $400 \mathrm{~m}$ apart. This randomized design ensured sample independence, allowing us to consider each transect as true replicates by avoiding repetition of a single transect in successive monthly samplings. Transects of $500 \mathrm{~m}$ long were walked by a single observer in search of feces. The exact perpendicular distance from the path to each encountered feces was measured with metric tape by an assistant. Thus, the observer never left the transect, avoiding the record of additional feces. All encountered feces were collected to avoid double counting. Density of $R . p$. garleppi was calculated monthly using Distance 6.0 software (Thomas et al. 2009), which requires entering data on individuals' defecation rate and feces permanence in the study area (Buckland et al. 2001). As we did not have defecation rate data for $R$. p. garleppi, we used data from a similar species $R$. americana, following Buckland et al. (2001). These species are phylogenetically closely related (Delsuc et al. 2007), have similar body weight and size (Fowler 1991; Navarro et al. 1998; Navarro et al. 2005), and exhibit a primarily herbivorous diet (Bonino et al. 1986; Martella et al. 1996). The defecation rate used was 13.5 feces/individual/day $( \pm 3.1 ; n=8)$ and the permanence time of the feces was 88.15 days $( \pm 6.4 ; n=14$ ) (NV Marinero, personal observation). To calculate monthly density, we used the negative exponential model with cosine extension (Figure 1). The monthly abundance of $R . p$. garleppi was determined by multiplying density value of each month by the reserve area $\left(400 \mathrm{~km}^{2}\right)$, following Ojasti and Dallmeier (2000). Population size range of $R$. p. garleppi was calculated considering the average of months with highest density as the upper limit and the average of months with lowest density as the lower limit. Abundance (dependent variable) as a function of months (fixed effect) was calculated using a heteroscedastic mixed model, considering the sampling years (2011 and 2012) as random effect. In addition, given the heteroscedasticity of our data, we indicated that error variance of abundance was different for each month (grouping criterion) in the mixed model, using the function VarIdent (Di Rienzo 2011). An a posteriori comparison of means of monthly abundance was performed using the Fisher's least significant difference (LSD) test, when differences were significant at $P \leq 0.05$ (Balzarini et al. 2008). Data were $\log _{10}$-transformed for normalization of residuals. Non-transformed data were expressed as mean \pm standard error of the mean. Statistical analyses were performed using Infostat (Di Rienzo et al. 2014).

Population size of the subspecies $R$. p. garleppi presented significant variations among months $\left(F_{5.84}=3.61\right.$; $P=0.002)$. The upper limit of the population was 0.75 ind $/ \mathrm{km}^{2}( \pm 0.15)$ and was recorded in March, April, and July (2012) $(P \leq 0.05)$ (Figure 2). This density is the highest published until now, but close to other records obtained in Argentina: $0.67 \mathrm{ind} / \mathrm{km}^{2}\left(29^{\circ} 25^{\prime} 60^{\prime} \mathrm{S}, 66^{\circ} 50^{\prime} 60^{\prime \prime} \mathrm{W}, \mathrm{La}\right.$ Rioja) and 0.52 ind $/ \mathrm{km}^{2}$ in Laguna de Pozuelo Biosphere Reserve $\left(22^{\circ} 28^{\prime} \mathrm{S}, 6^{\circ} 02^{\prime} \mathrm{W}\right.$, Jujuy) (Cajal 1988; Cajal 1998; and references therein). The differences in density estimates might be due to the different methods used, considering that Cajal (1988) states that the use of a motor vehicle to conduct the surveys of R. p. garleppi might have led to density underestimation. By contrast, we used the line-transect method and fit a detection function of probability of signs, which decreases with distance to the observer. This method reduces the potential bias of the density estimator (Buckland et al. 2001) and provides a more realistic value of a population's density and abundance in a given area (Thomas et al. 2013). The lower limit of R. p. garleppi population density was $0.47 \mathrm{ind} / \mathrm{km}^{2}$ $( \pm 0.10)$ in November $(2011$ and 2012$)(P \leq 0.05)$ (Figure 2$)$. 


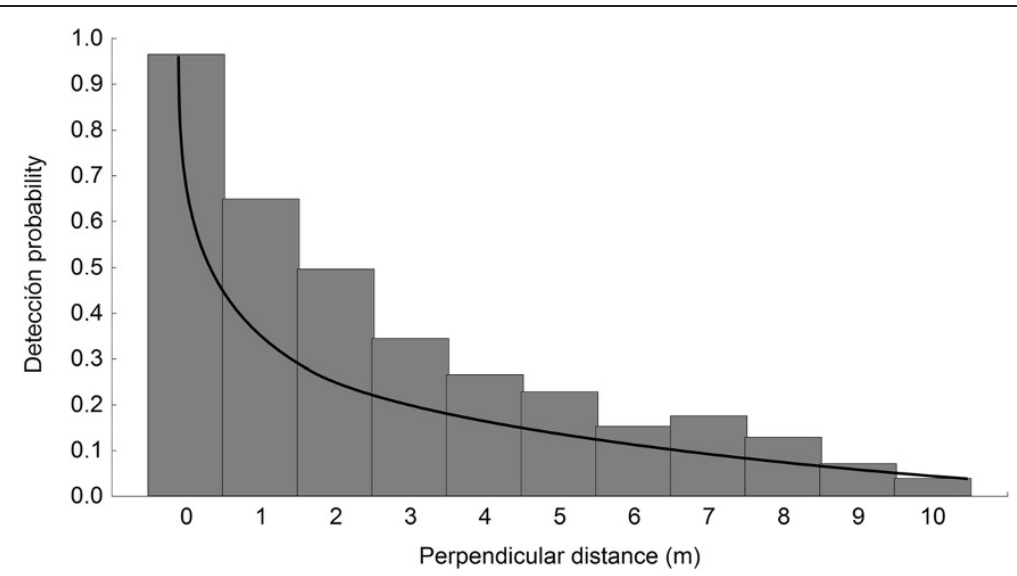

Figure 1 Histogram of the perpendicular distance of feces of R. p. garleppi recorded at Don Carmelo Private Reserve, San Juan, Argentina. The line represents the fit of the negative exponential function with cosine extension.

Although this record is the lowest for our study population, it is still higher than records reported for other wild populations inhabiting Argentina and Perú: $0.41 \mathrm{ind} / \mathrm{km}^{2}$ in Olaroz (234' S, 66 $6^{\circ} 48^{\prime}$ W, Jujuy) (Cajal 1998 and references therein), $0.12 \mathrm{ind} / \mathrm{km}^{2}$ in Laguna Blanca Biosphere Reserve $\left(26^{\circ} 28^{\prime} \mathrm{S}, 66^{\circ} 48^{\prime} \mathrm{W}\right.$, Catamarca), $0.03 \mathrm{ind} / \mathrm{km}^{2}$ in San Guillermo Biosphere Reserve $\left(29^{\circ} 25^{\prime} \mathrm{S}, 69^{\circ} 15^{\prime} \mathrm{W}\right.$, San Juan) and 0.01 ind $/ \mathrm{km}^{2}$ in Tacna $\left(16^{\circ} 44^{\prime} \mathrm{S}, 70^{\circ} 16^{\prime} \mathrm{W}\right)$ (Cajal 1988; Lleellish et al. 2007). Taking into account the important wild population of the subspecies garleppi present in the study area, it is necessary to promote its in situ conservation because it might become a source of individuals for possible recolonization and/or reinforcement of other populations undergoing higher conservation threat.

The higher abundance values of $R$. p. garleppi, with 300 individuals $( \pm 60)$, were recorded during March, April, and July $2012(P \leq 0.05)$ (Figure 2). The record of this upper limit in population size coincided with the occurrence of social groups of $R$. p. garleppi composed

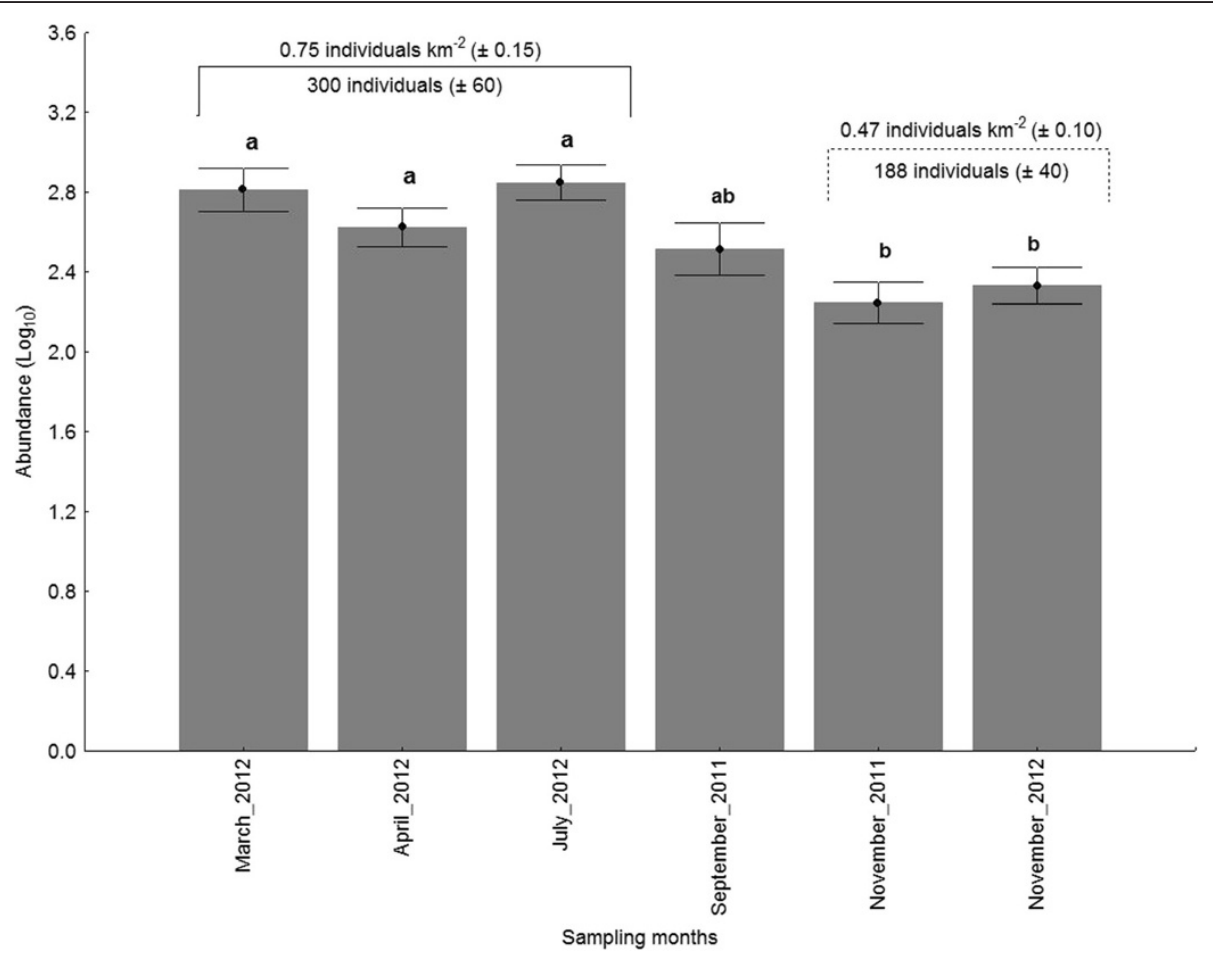

Figure 2 Variation of monthly abundance of R.p. garleppi in 2011 and 2012 in Don Carmelo Private Reserve, San Juan, Argentina. Solid line, upper limit of population size; dashed line, lower limit of population size. Different letters indicate significant differences (Fisher's LSD, $P \leq 0.05)$. 
of juveniles, females with juveniles, and males in the reserve (NVM, pers. obs.); this group composition is characteristic of the non-reproductive season of rheas (Hanford and Mares 1985; Sarasqueta 1990; Carro and Fernandez 2008). Thus, the observed increase in population size might be due to a reduction of aggressive behaviors among individuals during the non-breeding season, favoring the formation of groups of numerous individuals that tend to move together (Sarasqueta 1990). However, it is also very important to consider that the upper limit in the population size of $R . p$. garleppi could be due to the movements made by the individuals to the reserve in search of refuge from poaching and livestock production, two activities that are more intensively conducted in the surrounding fields during the nonbreeding season of the subspecies garleppi (Ordoñez 2006). This perception of a protected area as refuge from the surroundings has also been described for other native herbivores, such as Lama guanicoe in the Monte arid ecoregion in Argentina (Acebes et al. 2010). Moreover, abundance fell to 188 individuals $( \pm 40)$ in November (2011 and 2012) (Figure 2). This lower limit of population size corresponds to the breeding season of $R$. p. garleppi. While there was a record of an orphan egg in September 2012, no nest was found, despite the intensive search made inside the reserve. This drop in the number of individuals may be related to the species' nesting preferences, since individuals tend to select sites with high shrub cover, instead of pastures, which favors concealment and protection against predators and severe climate conditions (Bellis et al. 2006; Barri et al. 2009a). These sites are scarce in the study area, where shrub cover is only $16 \%$, and pastures are $24 \%$, whereas the remaining cover corresponds to bare soil (NV Marinero, unpublished data). Therefore, it is likely that during the reproductive season, $R$. p. garleppi individuals move toward surrounding areas about $14 \mathrm{~km}$ away from the reserve and below $2.500 \mathrm{~m}$ a.s.l. (NVM personal observation), where the habitat is dominated by an open shrubland of $L$. divaricata (Márquez 1999). Indeed, reproductive groups of males with females, males with chicks, and juveniles have been observed in this environment adjacent to the reserve (NV Marinero, unpublished data).

We were not able to compare our results with wild populations from Bolivia because there are no studies published on the density of $R$. p. garleppi in that country, despite the heavy use of this subspecies by local communities, to the extent that wild populations may be decimated (Balderrama 2009).

Our density records of $R . p$. garleppi (Figure 2) are higher than density values of $R$. p. tarapacensis present in different protected areas of Chile, which vary between 0.002 ind/ $\mathrm{km}^{2}$ (Isluga Volcano National Park, 199'5" S, 68 49'27" W) and 0.022 ind $/ \mathrm{km}^{2}$ (National Monument Salar Surire, $18^{\circ} 49^{\prime} 41^{\prime \prime}$ S, 69 3'39" W) (Acuña et al. 2008). However, our estimations are lower than the values recorded for $R . p$. pennata in the Patagonia of Chile and Argentina, with records of 8 ind $/ \mathrm{km}^{2}\left(50^{\circ} 46^{\prime} \mathrm{S}, 74^{\circ} 6^{\prime} \mathrm{W}\right.$, Ultima Esperanza, Chile), $2.93 \mathrm{ind} / \mathrm{km}^{2}$ (Santa Cruz, Argentina), $2.51 \mathrm{ind} / \mathrm{km}^{2}$ (Chubut, Argentina), 2.06 ind $/ \mathrm{km}^{2}$ and $1.55 \mathrm{ind} / \mathrm{km}^{2}$ (Rio Negro, Argentina), and 1.94 ind $/ \mathrm{km}^{2}$ (Neuquén, Argentina), although higher than in some areas of its northern distribution in Neuquén province, Argentina (Servicio Agrícola y Ganadero SAG 2002; Navarro et al. 1999; Secretaría de Ambiente y Desarrollo de la Nación SAyDS 2000; Novaro et al. 2000; Barri et al. 2009b). In Argentina, in general, R. p. garleppi would occur at lower densities than R. $p$. pennata, which could be related to the primary productivity of the ecosystems. Specifically, the subspecies $R . p$. garleppi is distributed throughout the Puna ecoregion, where the low biomass production in the environment determines a lower carrying capacity. By contrast, the Argentine Patagonia, where $R$. p pennata occurs, comprises a wider range of environments; the Monte and the Patagonia phytogeographic provinces, the Monte-Patagonia ecotone as well as 'mallines' (patchily distributed wetland areas), which provide habitat this ratite with important food resources (Oesterheld et al. 1998; Bellis et al. 2006; Guevara et al. 2006; Bianchi and Bravo 2008).

This work provides the highest density record for $R$. $p$. garleppi so far and highlights changes in population size related to the characteristics of the life history of rheas and human factors that negatively affect the survival of wild populations.

\section{Competing interests}

The authors declare that they have no competing interests.

\section{Authors' contributions}

NVM designed the study, collected the data, carried out the statistical analysis, and drafted the manuscript. RCO contributed to data acquisition and drafted the manuscript. JLN participated in the analysis and interpretation of results and in writing the manuscript. MBM conducted the fund raising, participated in the design of the study, the analysis, and interpretation of results, and in writing the manuscript. All authors read and approved the final manuscript.

\section{Authors' information}

NVM is a fellow and JLN and MBM are researchers of the Consejo Nacional de Investigaciones Científicas y Técnicas (CONICET) and teachers of the Universidad Nacional de Córdoba.

\section{Acknowledgements}

We are grateful to Arturo Curatola for allowing us to carry out this research on Don Carmelo Private Reserve. This work was funded by grants to MBM from the Secretaría de Ciencia y Tecnología de la Universidad Nacional de Córdoba (SECyT UNC) and the Agencia Nacional de Promoción Científica y Tecnológica de Argentina (FONCyT). We are grateful to the anonymous reviewers for their comments that helped improve a previous version of this manuscript.

\section{Author details}

${ }^{1}$ Instituto de Diversidad y Ecología Animal (Consejo Nacional de Investigaciones Científicas y Técnicas Universidad Nacional de Córdoba), 
Centro de Zoología Aplicada, Universidad Nacional de Córdoba, Rondeau 798, Córdoba X5000AVP, Argentina. ²Departamento de Biología, Universidad Nacional de San Juan, Argentina. Av. Ignacio de la Roza 590 (Oeste), San Juan 5000, Argentina.

\section{Received: 21 March 2014 Accepted: 10 July 2014}

Published online: 04 September 2014

\section{References}

Acebes P, Traba J, Malo JE, Ovejero R, Borghi CE (2010) Density and habitat use at different spatial scales of a guanaco population (Lama guanicoe) in the Monte Argentina. Mammalia 74:57-62

Acuña MP, Estades CM, Gonzáles BP, Hernández JP, Vukasovic MF, Villaseñor NP (2008) Evaluación poblacional del suri (Rhea pennata tarapacensis) en las regiones de Arica, Parinacota, y de Tarapacá. Informe Final, CONAF, Chile

Balderrama JA (2009) Libro rojo de la fauna silvestre de vertebrados de Bolivia. Ministerio de Medio Ambiente y Agua, La Paz

Balzarini MG, Gonzalez L, Tablada M, Casanoves F, Di Rienzo JA, Robledo CW (2008) Manual del Usuario. Editorial Brujas, Córdoba, Argentina

Barbarán F (2004) Usos mágicos, medicinales y rituales de la fauna en la Puna del Noroeste Argentino y Sur de Bolivia. Contribuciones al Manejo de Vida Silvestre en Latinoamérica 1(1):1-26

Barri FR, Martella MB, Navarro JL (2009a) Reproductive success of wild Lesser Rheas (Pterocnemia -Rhea- pennata pennata) in north-western Patagonia, Argentina. J Ornithol 150:511-514

Barri FR, Martella MB, Navarro JL (2009b) Nest-site habitat selection by Lesser Rheas (Rhea pennata pennata) in northwestern Patagonia, Argentina. J Ornithol 150:511-514

Bazzano G, Martella MB, Navarro J, Bruera N, Corbella C (2002) Uso de hábitat por el Ñandú (Rhea americana) en un refugio de vida silvestre: implicancias para la conservación y manejo de la especie. Ornitol Neotrop 13:9-15

Bellis LM, Navarro JL, Vignolo PE, Martella MB (2006) Habitat preferences of lesser rheas in Argentine Patagonia. Biodivers Conserv 15:3065-3075

Bianchi AR, Bravo GC (2008) Ecorregión norandina. Descripción, subregiones, agroecosistemas, sistemas productivos y cartografía regional. Ediciones INTA, Salta

Blake ER (1977) Manual of neotropical birds: volumen 1: Spheniscidae to Laridae. Chicago Univ. Press, Chicago, Illinois

Bonaparte J (1978) El mesozoico de América del Sur y sus tetrápodos, Opera Lilloana 26. Universidad Nacional de Tucumán. Fundación Miguel Lillo, Tucumán

Bonino N, Bonvissuto G, Pelliza-Sbriller A, Somlo R (1986) Hábitos alimentarios de los herbívoros en la zona central del área ecológica sierras y mesetas occidentales de Patagonia. Revista Argentina de Producción Animal 6:275-287

Buckland ST, Anderson DR, Burnham KP, Laake JL, Borchers DL, Thomas L (2001) Introduction to distance sampling: estimating abundance of biological population. OXFORD University Press, Great Britain

Cabrera A (1976) Regiones fitogeográficas Argentinas: Enciclopedia de agricultura y jardinería. Tomo II, Fascículo 1. ACME, Buenos Aires

Cabrera A, Willink A (1973) Biogeografía de América Latina. Secretaría General de la Organización de Estados Americanos, Washington D.C

Cajal JL (1988) The Lesser Rhea in the Argentine Puna region: present situation. Biol Conserv 45:81-91

Cajal JL (1998) Una especie frágil: el ñandú petizo: bases para la conservación y Manejo de la Puna y Cordillera Frontal de Argentina. In: Cajal J, Tecchi R (eds) El rol de las Reservas de Biosfera. UNESCO, Uruguay

Cappa F, Borghi CE, Campos VE, Andino N, Reus ML, Giannoni SM (2014) Guanacos in the Desert Puna: a trade-off between drinking and the risk of being predated. J Arid Environ 107:34-40

Carro M, Fernandez G (2008) Seasonal variation in social organization and diurnal activity budget of the Greater Rhea (Rhea americana) in the Argentinean pampas. Emu 108(2):167-173

Chebez J (2008) Los que se van: Individuos. Ed. Albatros, Buenos Aires, Argentina

CITES (2014) Convention on international trade in endangered species of wild fauna and flora., www.cites.org. Acceso 2 July 2014

Delsuc F, Superina M, Ferraris G, Tilak M, Douzeri EJ (2007) Molecular evidence for hybridization between the two living species of South American ratites: potential conservation implications. Conserv Genet 8:503-507

Di Rienzo JA (2011) Modelos lineales mixtos: aplicaciones en InfoStat / JA Di Rienzo, RE Macchiavelli; F Casanoves - 1a. Grupo Infostat, Córdoba

Di Rienzo JA, Casanoves F, Balzarini MG, Gonzalez L, Tablada M, Robledo CW (2014) InfoStat versión 2014. Grupo InfoStat, FCA, Universidad Nacional de Córdoba, Argentina, URL http://www.infostat.com.ar
Folch A (1992) Order Struthioniformes. In: Del Hoyo J, Elliot A, Sargatal J (eds) Handbook of the birds of the world, vol 1. Lynx Edicions, Barcelona

Fowler ME (1991) Comparative clinical anatomy of ratites. J Zoo Wildlife Med 22:204-227

Guevara JC, Bertiller MB, Estevez OR, Grünwaldt EG, Allegretti LI (2006) Pastizales y producción animal en las zonas áridas de Argentina. Science et changements planétaires Sécheresse 17:245-256

Hanford PT, MARES MA (1985) The mating systems of ratites and tinamous: an evolutionary perspective. Biol J Linn Soc 25:77-104

Hernandez JH (2011) Percepción por parte de los pobladores en la zona de influencia de la reserva de Biósfera San Guillermo (San Juan) acerca de aspectos relacionados con la fauna silvestres y su manejo. Tesina de grado. Universidad Nacional de San Juan, San Juan, Argentina

Herrera LP, Camparatore VM, Laterra P (2004) Habitat relations of Rhea americana in an agroecosystem of Buenos Aires Province, Argentina. Biol Conserv 119:363-369

IUCN (2014) Red list of threatened species., www.iucnredlist.org. accessed 2 July 2014

Kusch A, Henríquez M (2011) Preferencias de hábitat del Ñandú (Rhea pennata D'Orbigny, 1834) en matorrales intervenidos de Chile austral. Anales Instituto Patagonia 39(1):43-50

Lleellish M, Salinas L, Chipana E (2007) Estado de conservación del Suri Pterocnemia pennata en el Perú: serie de publicaciones de flora y fauna silvestre. Instituto Nacional de Recursos Naturales, Lima

Márquez J (1999) Las áreas protegidas de la provincia de San Juan. Multequina $8: 1-10$

Martella MB, Navarro JL, Gonnet JM, Monge SA (1996) Diet of greater rheas in an agroecosystem of central Argentina. J Wildlife Manage 60(3):586-592

Navarro JL, Bellis LM, Lábaque MC, Martella MB (1998) Crecimiento de pichones de choiques en criaderos: implicancias en el consumo y costos de alimentación: conservación y manejo del choique en patagonia. In: Robles C, Navarro J (eds). Ediciones 2000. INTA, Bariloche, Argentina

Navarro JL, Cabrera MB, Funes M, Cardón R, Manero A (1999) Abundancia de Choiques en granjas de Patagonia. In: Informe a la Dirección de Fauna y Flora Silvestres, Secretaría de Recursos Naturales y Desarrollo Sustentable

Navarro JL, Vignolo PE, Demaria MR, Maceira NO, Martella MB (2005) Growth curves of farmed Greater Rheas (Rhea americana albescens) from central Argentina. Archiv Für Geflügelkunde 69:90-93

Novaro AJ, Funes MC, Walker R (2000) Ecological extinction of native prey of carnivore assemblage in Argentine Patagonia. Biol Conserv 92:25-33

Oesterheld M, Aguiar MR, Paruelo JM (1998) Ecosistemas patagónicos. Ecología Austral 8:75-84

Ojasti J, Dallmeier F (2000) Manejo de Fauna Silvestre Neotropical: SI/MAB Series 5. Smithsonian Institution/MAB Biodiversity Program, Washington D.C

Ordoñez C (2006) Uso del hábitat por Pterocnemia pennata e interacciones con herbívoros silvestres (Ctenomys y Lama guanicoe) y domésticos (Equus caballus) en la reserva privada de uso mútiple Don Carmelo (Puna sanjuanina)": Tesina de licenciatura. Univ. Nacional de San Juan, San Juan. Argentina

Plenge M (1982) The distribution of the lesser rhea Pterocnemia pennata in southern Perú and northern Chile. Ibis 124:168-172

Reboratti C (2006) Situación ambiental en las ecorregiones Puna y Altos Andes. In: Brown A, Martinez U, Acerbi M, Corchera J (eds) La situación ambiental argentina 2005. Fundación Vida Silvestre Argentina, Buenos Aires

Sarasqueta DV (1990) Aspectos de la biología reproductiva del Ñandú petiso (Pterocnemia pennata). Comunicación técnica №1. INTA

Secretaría de Ambiente y Desarrollo de la Nación SAyDS (2000) Propuesta de enmienda para transferir Pterocnemia pennata pennata desde el Apéndice I al Apéndice II de CITES. Jefatura de ministros. Buenos Aires, Argentina

Servicio Agrícola y Ganadero SAG (2002) Propuesta de enmienda para transferir Pterocnemia pennata pennata desde el Apéndice I al Apéndice II de CITES. XII Conferencia de las Partes de CITES, Santiago, Chile

Thomas L, Laake JL, Rexstad E, Strindberg S, Marques FC, Buckland S, Borchers DL, Anderson DR, Burnham KP, Burt ML, Hedley SL, Pollard JH, Bishop JRB, Marquez TA (2009) Distance 6.0: release 2. St Andrews Research Unit for Wildlife Population Assessment, University of St Andrews, Scotland, http:// distancesampling.org/Distance/index.html

Thomas L, Buckland ST, Burnham KP, Anderson DR, Laake JL, Borchers DL, Strindberg S (2013) Distance sampling. Encyclopedia of Environmetrics 2

doi:10.1186/s40693-014-0017-z

Cite this article as: Marinero et al:: Density and abundance of Rhea pennata garleppi (Struthioniformes: Rheidae) in the Puna ecoregion of Argentina. Revista Chilena de Historia Natural 2014 87:17. 